\title{
OBITUARIES
}

\section{Sir James McNeill, K.C.V.O., C.B.E., F.R.S.}

James McFadyen McNeill, who died on July 24, was born in 1892, at Clydebank, where, in 1870, the establishment of a shipyard and engine works had led to the foundation of a burgh. His schooling was first local, and then in Glasgow at Allan Glen's, a school notable for the opportunity offered to aspirants toward engineering. His father was a foreman in the shipyard of John Brown and Co., and in 1908 James McNeill began an apprenticeship there, and an association which, with only a war-time interruption, was to be continuous. In those days, a technical education was a luxury which had to follow a normal apprenticeship, and it was not until 1912 that James MeNeill, with a good knowledge of shipbuilding as a background, matriculated at the University of Glasgow. In 1915 he graduated as B.Sc., the leading student of naval architecture in his group, winner of prizes in engineering and in mathematics as well as in his own specialized subject, and, withal, quiet and unassuming; an indication of another interest was attendance at the class of political economy. Graduation was soon followed by enlistment, with the Royal Artillery as the choice. In the German offensive of early 1918 the conduct of Captain James McNeill as a battery commander gained for him a mention in despatches, a Military Cross, and promotion to field rank.

Back to the shipyard after the War, James McNeill was placed in charge of the design and technical section associated with the ship drawing office. It was fairly soon apparent that in the years of war there had been marked development of latent qualities-acceptance of responsibility and exercise of leadership. The development was recognized when, in 1928, following an unexpected vacancy, the young man was appointed naval architect to the Company, a position carrying responsibility for the preparation of all shipyard plans, from the design stage onwards to completion, and leading in a few years to a seat on the local board of directors. The first major work carried out by James McNeill was the design and completion of the Empress of Britain, the largest ship built in Great Britain since the completion of the Aquitania in 1914; there had been keen competition for the contract, and there were stringent conditions to be fulfilled. In the launching of this large ship a feature new in Britain was the use of ciné cameras, and the painting of 'register' marks on the hull, in order that a complete and reliable record could be obtained of the travel of the ship down the launching ways and, especially, of the 'plunge' as the fore end of the launching cradle dropped off the end of the ways; the placing of some of the cameras involved some of the technique of the skilled gunner.

The record of the launching of the Empress of Britain was valuable in itself. There was, however, special intent behind it. Consideration was already being given to the problem of building and launching a ship about 1,000 ft. long, and the cost of the dredging necessary to permit the launching into a restricted river was a factor to be taken into account. From the records of the launch of the Empress of Britain it was found that the dredging need not be so extensive as had been feared. The successful launching of the Queen Mary in 1934 was, in a way, a development from the launching of the Empress of Britain. There was also, however, much fresh and patient investigation of the whole range of problems involved in what is at once a crude and a highly complicated operation. A comprehensive record of the investigations and of the treatment of the problems was presented to the Institution of Naval Architects in 1935 in a paper by Mr. McNeill which is a masterpiece.

The patient and perceptive thoroughness which $\mathbf{M r}$. McNeill had displayed in his first major work for John Brown and Co. was carried on throughout his career in the shipyard. The range of his activity was wide, and although the Queen Mary and Queen Elizabeth are his masterpieces, he left his mark on lesser-known craft of all types. In 1948 he became managing director of the establishment to which he had come as an apprentice forty years before: and then in 1953 he became deputy chairman of the Company, a position he held until retirement in 1962. A catalogue of honours includes first the honorary degree of LL.D. from the University of Glasgow in 1939, election as a Fellow of the Royal Society in 1948, Royal appointment as C.B.E. in 1950, and as K.C.V.O. in 1954. Appreciation of colleagues in the shipbuilding and engineering industry was shown by selection for high office in the ancillary organizations of the industry, and in the professional institutions.

In Sir James McNeill there was much more than technical capacity. There was staunch integrity, allied to wisdom and kindliness, qualities which won the respect of all who were concerned with ships produced at Clydebank, whether as owners of ships or as officers of Government. With a streak of the puritan in him, he could come down hard on any tendency toward vulgarity in the conversation across the shipyard lunch-table. He could express strong dislike of income tax 'fiddling', and also of bullying of juniors-to him, bullying was the resort of the man who was not up to his job. A. M. RoBB

\section{Prof. Louis Fage}

THE well-known French zoologist, Louis Fage, member of the Académie des Sciences, Commandeur de la Légion d'Honneur, died in Dijon on May 28, in his eighty-first year. Formerly professor at the Muséum National d'Histoire Naturelle, Paris, and at the Institut Océanographique, he was outstanding as investigator, lecturer and administrator. His publications include the volumes on Amphipoda (with Chevreux, 1925) and Cumacea (1951) in the Faune de France, and the sections on Merostomata and Pycnogonida in Grassé's Traité de Zoologie (1949).

He was born on September 30, 1883, in Limoges (HautVienne), France, son of René Fage, barrister and corresponding member of the Académie des Inscriptions et Belles-Lettres. $\mathrm{He}_{e}$ was educated at the Collège St. Martial, Limoges, and entered the University of Paris in 1900 , still undecided as to his course of study. It so happened that Gaston Bonnier and Edmond Perrier were old family friends; on their advice he chose the natural sciences and obtained his doctorate in 1906. Forty years later Goodrich referred to his thesis on the segmental organs of polychrte worms as the most important of the general works on nephridia and allied subjects which had appeared since 1895 .

For the next fourteen years he served as naturalist to the Service Scientifique des Pêches Maritimes, attached to the Laboratoire Arago, Banyuls, of which Racovitza was the resident deputy director. His work on Mediterranean fishes attracted the attention of the oceanographer, Johannes Schmidt, and led to a life-long association with Danish scientists. $\mathrm{H}_{\theta}$ found the local methods of catching pelagic shoaling fishes rudimentary in the extreme and suggested fishing with lights at night. $\mathrm{He}$ also used this method extensively for the collection of plankton; this work, started in the Mediterranean, 
was continued over a period of years at Concarneau with Legendre and groatly extended our knowledge of the biology of many littoral invertebrates. During this period he also became interested in Arachnida and in speleology. He joined Racovitza and Jeannel, founders of the association known as Biospeologica, in their explorations and described the cavernicolous spiders. This had an interesting sequel; in 1947 Fage put the case for a subterranean research laboratory to the director of the Centre National de la Rechorche Scientifique (C.N.R.S.) so successfully that soon afterwards the laboratory at Moulis (Ariège) was opened.

The year 1920 marked a turning point in Fage's scientific career. At the invitation of Charles Gravier he joined the staff of the Muséum National d'Histoire Naturelle, Paris, as deputy director of the zoological laboratory, in charge of various invertebrate phyla. He became director of the laboratory in 1938, a post he held conjointly with his professorships until his retirement in 1953. To commemorate his scientific jubilee he was presented just after his seventieth birthday with a gold medal specially designed by Robert Cochet.

Fage also played a prominent part in scientific activities outside the Museum and outside France. For example, during 1924-27 he was secretary of the Société de Biogéographie, of which he was a founder member. He was president of the Société zoologique (1929), the Société entomologique (1935) and the Académio des Sciences (1955). He was secretary-general of the Permanent Committee of the International Congresses of Zoology (194853) and represented the Institut Océanographique on the Conseil International pour l'Exploration do la Mer, the Commission pour l'Exploration de la Mediterranéo and the Commission internationale d'Océanographie. A member of the C.N.R.S., he was chairman of the Bathyscaphe-Calypso Committee and of the Moulis Laboratory Committee. For many years he was editor or co-editor of various periodicals such as the Archives de Zoologie expérimentale et générale and the Annales de l'Institut Océanographique; he was a co-oditor of Deep Sea Research from its inception in 1953.

Over a period of almost sixty years Fago published some 250 scientific papers, monographs and books dealing with many quite unrelated groups of animals from Protozoa to fishes. Although much of his museum work was of necessity taxonomic, he was pre-eminently a field naturalist interested in the living animals, their habits, habitats and life-histories, their geographical distribution in relation to environmental factors, their evolution. An authority on Arachnida, he described the habits of spiders that lead an amphibious life among tropical corals or the encrusting calcareous algal growths (the 'trottoir') of Mediterranean shores, that live normally in the urns of pitcher plants or as commensals in the nests of ants and termites. He studied the development, metamorphosis, growth, spawning and migrations of many coastal fishes, and applied biometric methods to the elucidation of the different races of sardine and anchovy. He found that many bottom-living invertebrates, especially annelids, cumaceans, amphipods, mysids and sea-spiders, have pelagic phases which are subject to nycthemeral, lunar and seasonal rhythms, and that many supposedly rare sedentary species may be captured in thousands at certain times. His Dana Reports on the primitive mysidacean order Lophogastrida (1941) and (1942) and on the pelagic amphipod family Oxycephalidae (1960) deserve special mention. The vast amount of material (for example, Gnathophausia 875, Ceratolepis 174 and oxycephalids 35,000 specimens), available for the first time, enabled him to add much to our knowledge of the systematics, chorology, sexuality and parasites of the species represented. In the field of oceanography he investigated the influence of the organic content of marine sediments on the distribution and density of the abyssal benthic fauna; also the variation in the amount of oxygen dissolved in the sea-water immediately above the sedi. ments. For an account of Fage as speleologist the reader is referred to Prof. Vandel's obituary note in Annales de Spéléologie (19 (2), 245; 1964).

Fage was a foreign member of many scientific societies, including the Zoological and Linnean Societies of London. Of the many honours which were conferred on him, he must, one imagines, have valued highly the gold medal of the Johannes Schmidt Foundation for the Exploration of the Sea (1958). All this notwithstanding, he was without ostentation, modest, sincere and kind, at his charming best when entertaining a few friends in his own home. His wife, née Marie Marguerite Gigaud-Lafont, predeceased him by about three years; they had one son and one daughter. ISABELIA GORDON

\section{NEWS and VIEWS}

\section{The Royal Society: S. G. Brown Medal and Award}

IN January 1964 the Council of the Royal Society announced the establishment of a fund, following a bequest under the will of the late S. G. Brown, the income from which would be used to offor annually an S. G. Brown Award and Medal for an outstanding contribution, based on work carried out during the preceding five years, to tho promotion and development of mechanical inventions (Nature, 201, 556; 1964). Recommendations for the award were to be made to the Council by the Councils of the Institutions of Civil, Mechanical and Electrical Engineers in rotation. It has now been announced that the first award has been made to Mr. F. M. Adler a civil engineor, for his work in the promotion and development of the 'Jackblock' technique, a system for the construction of tall buildings providing factory conditions during orection. The roof is constructed first, at ground level, and then raised by jacks for the top-most floor to be constructed beneath it, and so on. During the process cach floor travels vertically through a 'factory' in which all the services, fittings and finishes are installed. A 17-storey block of flats has recently been completed at Coventry using this technique.

\section{Biochemistry in University College, Dublin : Prof. E. J. Conway, F.R.S.}

Prof. E. J. Conwax retired from the chair of biochemistry and pharmacology in University College, Dublin, on October 29. After a brilliant undergraduate career in that University, ho graduated in science in 1916 and in medicine in 1921. There followed a vigorous resoarch programme on renal physiology in the Physiology Department under Prof. J. M. O'Connor on the basis of which he was awarded the D.Sc. dogreo in 1927. As a Rockefeller Fellow he worked for two years with Embden at Frankfurt. On returning to Dublin he was appointed to the chair of biochemistry and pharmacology in 1932. During the thirty-two years that he occupied the chair, Prof. Conway published two books and more than 150 research papers, monographs and review articles. In addition to his earlier work on renal physiology, he is well known internationally for his contributions to the mechanisms of electrolyte oxchanges between cells and their environment, the evolutionary origins of such environments, the mechanism of gastric acid secretion and the technique of microdiffusion analysis. His outstanding place in world science can best be assessed in terms of the honours which 